\title{
Assessment of Consciousness Energy Healing Treatment on Immune Biomarkers After Oral Administration of Herbomineral Formulation in Sprague Dawley Male Rats
}

\author{
Mahendra Kumar Trivedi ${ }^{1}$, Alice Branton ${ }^{1}$, Dahryn Trivedi ${ }^{1}$, Gopal Nayak ${ }^{1}$, Aileen Carol Lee ${ }^{1}$, \\ Aksana Hancharuk ${ }^{1}$, Carola Marina Sand ${ }^{1}$, Debra Jane Schnitzer ${ }^{1}$, Rudina Thanasi ${ }^{1}$, \\ Eileen Mary Meagher ${ }^{1}$, Faith Ann Pyka ${ }^{1}$, Gary Richard Gerber ${ }^{1}$, Johanna Catharina Stromsnas ${ }^{1}$, \\ Judith Marian Shapiro ${ }^{1}$, Laura Nelson Streicher ${ }^{1}$, Lorraine Marie Hachfeld ${ }^{1}$, \\ Matthew Charles Hornung ${ }^{1}$, Patricia M. Rowe ${ }^{1}$, Sally Jean Henderson ${ }^{1}$, Sheila Maureen Benson ${ }^{1}$, \\ Shirley Theresa Holmlund ${ }^{1}$, Stephen P. Salters ${ }^{1}$, Mayank Gangwar ${ }^{2}$, Snehasis Jana ${ }^{2,}$ * \\ ${ }^{1}$ Trivedi Global, Inc., Henderson, USA \\ ${ }^{2}$ Trivedi Science Research Laboratory Pvt. Ltd., Bhopal, India
}

Email address:

publication@trivedieffect.com (S. Jana)

${ }^{*}$ Corresponding author

To cite this article:

Mahendra Kumar Trivedi, Alice Branton, Dahryn Trivedi, Gopal Nayak, Aileen Carol Lee, Aksana Hancharuk, Carola Marina Sand, Debra Jane Schnitzer, Rudina Thanasi, Eileen Mary Meagher, Faith Ann Pyka, Gary Richard Gerber, Johanna Catharina Stromsnas, Judith Marian Shapiro, Laura Nelson Streicher, Lorraine Marie Hachfeld, Matthew Charles Hornung, Patricia M. Rowe, Sally Jean Henderson, Sheila Maureen Benson, Shirley Theresa Holmlund, Stephen P. Salters, Mayank Gangwar, Snehasis Jana. Assessment of Consciousness Energy Healing Treatment on Immune Biomarkers After Oral Administration of Herbomineral Formulation in Sprague Dawley Male Rats. Biochemistry and Molecular Biology. Vol. 2, No. 6, 2017, pp. 110-119. doi: 10.11648/j.bmb.20170206.17

Received: October 22, 2017; Accepted: November 3, 2017; Published: December 11, 2017

\begin{abstract}
Herbomineral formulations have increased in recognition and popularity due to their high safety and better therapeutic benefits than other conventional methods. The aim of the present study was to evaluate the immunomodulatory effect of the Trivedi Effect ${ }^{\circledR}$ - Energy of Consciousness Healing Treatment on a new proprietary herbomineral formulation in male Sprague Dawley (SD) rats. The test formulation contained essential ingredients like the herbal root extract ashwagandha and minerals (zinc, magnesium, and selenium). The test formulation was divided into two parts. One part was denoted as the control without any Biofield Energy Treatment, while the other part was defined as the Biofield Treated sample, which received the Biofield Energy Healing Treatment remotely from eighteen renowned Biofield Energy Healers. The immunomodulatory effect of the Biofield Energy Treated and untreated test formulations was studied in SD rats to determine any alteration in humoral immune response (IgG and $\operatorname{IgM})$, cellular immune response, hematology, lipid profile, hepatic enzymes, and the testosterone. The Biofield Energy Treated test formulation group (G3) showed significantly increased levels of $\operatorname{IgM}$ and $\operatorname{IgG}$ by $46.15 \%$ and $14.92 \%$, respectively compared with the disease control group (G2). The cellular immune response (i.e. the ratio of $\mathrm{CD}^{+}$and $\mathrm{CD} 8^{+}$) was decreased by $76.47 \%$ in the Biofield Energy Treated test formulation compared with the G2 group. The hematology parameters such as TLC, neutrophils, lymphocytes, and monocytes were significantly increased by $18.01 \%, 1.34 \%, 12.34 \%$, and $0.67 \%$, respectively in the Biofield Energy Treated test formulation group compared with the G2 group. The lipid profile parameters viz. total cholesterol, triglycerides, HDL, LDL, and VLDL were significantly decreased in the Biofield Energy Treated test formulation group (G3) by $8.73 \%, 10.96 \%, 6.26 \%, 8.60 \%$, and 11.01\%, respectively compared with the G2 group. Among the tested hepatic parameters, results showed decreased levels of SGOT $(5.27 \%)$, SGPT $(17.70 \%)$, ALP $(0.26 \%)$, total protein $(5.8 \%)$, albumin $(5.47 \%)$, globulin $(9.27 \%)$, and albumin/globulin ratio $(1.34 \%)$ in the Biofield Energy Treated test formulation group compared with the G2 group. However, the Biofield Energy Treated test formulation group animals exhibited an increased level of testosterone by $39.8 \%$ compared with the G2 group. The overall results demonstrated that the Biofield Energy Treated test formulation showed a better immune response compared with the untreated test formulation. These experimental data suggest that the Trivedi Effect ${ }^{\circledR}$ - Energy of Consciousness
\end{abstract}


Healing Treatment based herbomineral formulation can be used for autoimmune and inflammatory diseases, stress management and anti-aging by improving overall health.

Keywords: Biofield Energy Healing Treatment, Biofield Energy Healers, Herbomineral Formulation, Immune-Modulation, Cellular and Humoral Immune Response, Hepatic Biomarkers, Anti-Aging, Inflammatory Disease and Stress Management

\section{Introduction}

In developing and developed countries alike, medicinal plant-derived drugs are continuously gaining popularity due to their natural origin, high safety, better therapeutic response, and less side effects. Many traditional and complementary medicines are derived from medicinal plants, minerals, and organic matter, which are commonly used for the prevention and treatment of many diseases. The therapeutic properties of plant extracts have been recognized and utilized worldwide since ancient times $[1,2]$. Scientific studies have identified the immunomodulatory properties of medicinal plants, which can be further potentiated with the addition of some minerals that regulate the immune cells. These types of formulations are well-defined as herbomineral formulations and are the major target of pharmaceutical companies as daily dietary supplements. The use of natural remedies has gained importance in cases when conventional medicines are ineffective for certain diseases, due to being natural, safe, and non-toxic in nature. Herbal and traditional medicine are suitable candidates for new therapeutics due to their vast chemical diversity and various biological effects [2]. Several marketed medicinal formulations are in use today, but safety is the serious concern that has developed. This concern has lead researchers to develop some natural compounds along with essential minerals, which are only required in minute quantities to boost the immune system while retaining a low toxicity profile [4]. With this respect, the authors of this study used a herbomineral formulation with a combination of Withania somnifera (ashwagandha) root extract and three minerals viz. zinc, magnesium, and selenium as a basis to investigate immunomodulatory potential. All the individual components have been reported with significant biological activities such as antioxidant, anti-inflammatory, anti-viral, and immune modulating [5-7]. In general, the ashwagandha plant has been reported for immunomodulatory activity, antitumor, antibacterial effects, a role in cancer treatment, and many more with available pre-clinical and clinical reports $[8,9]$. The important minerals such selenium, zinc, copper, magnesium, etc. have been reported for a beneficial role in immunomodulation [5].

According to the scientific studies and clinical trials, Biofield Energy Healing Treatments have been reported worldwide as an alternative treatment method, which has been known for having a significant impact on various cancerous cells [10]. According to many scientific studies, Biofield Energy Healings have been reported to have significant outcomes that may prove to be a more cost effective alternative to other approaches [11]. The use of
Complementary and Alternative Medicine (CAM) therapies have increased as the preferred models of treatment, among which Biofield Therapy (or Healing Modalities) is one approach that has been reported to have several benefits to enhance physical, mental, and emotional human wellness. Additionally, holistic medicine/integrative medicine addresses not only the entirety of the body, but the mind and spirit as well. However, Biofield Energy can exist in different forms like kinetic, magnetic, potential, electrical, and electromagnetic. The human body has the power to produce low intensity electromagnetic signals known as the Biofield. Thus, a human has the ability to harness energy from the environment and transmit it to any living or nonliving object (s) around the globe. The objects always receive the energy and respond in a useful way. This process is known as Biofield Energy Healing Treatment (The Trivedi Effect ${ }^{\circledR}$ ). Based on the literature data, Biofield Energy Treatments in terms of a Complementary and Alternative Medicine (CAM) approach have been practiced worldwide [12]. The National Center of Complementary and Integrative Health (NCCIH) has recognized and accepted Biofield Energy Healing as a Complementary and Alternative Medicine (CAM) health care approach in addition to other therapies, medicines and practices such as natural products, deep breathing, yoga, Tai Chi, Qi Gong, chiropractic/osteopathic manipulation, meditation, massage, special diets, homeopathy, progressive relaxation, guided imagery, acupressure, acupuncture, relaxation techniques, hypnotherapy, healing touch, movement therapy, pilates, Rolfing structural integration, and mindfulness, Ayurvedic medicine, traditional Chinese herbs and medicines, naturopathy, essential oils, aromatherapy, Reiki, and cranial sacral. To this day, Biofield Energy Healing has had a significant impact in the transformation of living organisms and nonliving materials. In addition, Biofield Energy Healing Treatment (The Trivedi Effect ${ }^{\circledR}$ ) outcomes have been published in numerous peer-reviewed science journals due to its significant impact in many scientific fields such as cancer research [13, 14], microbiology [15-18], genetics [19, 20], pharmaceutical science [21-24], agricultural science [25-28], and in materials science [29-32].

In this study, the authors sought to evaluate the impact of The Trivedi Effect ${ }^{\circledR}$ - Energy of Consciousness Healing Treatment on a herbomineral test formulation for its immunomodulatory potential in male Sprague Dawley (SD) rats with identification of cellular and humoral immune response, hematological parameters, lipid profile, hepatic 
enzymes, and sex hormone.

\section{Materials and Methods}

\subsection{Chemicals and Reagents}

The chemicals such as pyrogallol and carboxymethyl cellulose sodium were purchased from Sigma Chemical Co. (St. Louis, MO). Ashwagandha (Withania somnifera) root extract powder ( $\geq 5 \%$ of total withanolides) was procured from Sanat Products Ltd., India. Zinc chloride and magnesium (II) gluconate hydrate were procured from Tokyo Chemical Industry Co., Ltd. (TCI), Japan. Sodium selenate was procured from Alfa Aesar, USA. Levamisole hydrochloride was procured from Sigma, USA. All other chemicals used in this experiment were of analytical grade available locally.

\subsection{Laboratory Animals}

A total number of 30 healthy male Sprague Dawley rats, weighing between 150-250 grams, were used for the study. Rodent laboratory diet and drinking tap water were provided ad libitum under controlled conditions with a temperature of $22 \pm 3{ }^{\circ} \mathrm{C}$, humidity of $30 \%$ to $70 \%$ and a 12 hours light $/ 12$ hours dark cycle. The animals were acclimatized for the period of 5 days prior to the experiment, and all were accessed once daily for clinical signs, behaviors, morbidity and mortality. All the procedures were in strict accordance with the Guide for the Care and Use of Laboratory Animals published by the US National Institutes of Health. The approval of the Institutional Animal Ethics Committee that was obtained prior to carrying out the animal experiment.

\subsection{Energy of Consciousness Treatment Strategies}

The herbomineral test formulation was divided into two parts. One part of the test formulation was treated with the Biofield Energy by renowned Biofield Healers (also known as the Trivedi Effect ${ }^{\circledR}$ ) and coded as the Biofield Energy Treated formulation, while second part of the test formulation did not receive any sort of treatment and was defined as the untreated test formulation. The Trivedi Effect ${ }^{\circledR}$ - Energy of Consciousness Healing Treatment was provided through a group of eighteen Biofield Energy Healers who participated in this study and performed the Biofield Energy Treatment remotely. Eleven Biofield Energy Healers were remotely located in the U. S. A, four were remotely located in Canada, two in Finland, and one of which was remotely located in Albania, while the test herbomineral formulation was located in the research laboratory of Dabur Research Foundation, New Delhi, India. This Biofield Treatment was administered for 5 minutes through the Healer's unique Energy Transmission process remotely to the test formulation under laboratory conditions. None of the Biofield Energy Healers in this study visited the laboratory in person, nor had any contact with the herbomineral samples. Further, the control group was treated with a "sham" healer for comparative purpose. The sham healer did not have any knowledge about the Biofield Energy Treatment. After that, the Biofield Energy Treated and untreated samples were kept in similar sealed conditions and used for the study.

\subsection{Antigen (Sheep RBC)}

The fresh sheep blood was collected aseptically from the jugular vein of a healthy sheep and transferred immediately to the heparinized tube. The collected erythrocytes were separated from plasma by centrifugation $\left(400 \mathrm{~g}, 10^{\circ} \mathrm{C}, 10\right.$ minutes), washed twice with the normal saline and then further diluted in saline and the samples were analyzed using Hematology analyzer (Abbott Model-CD-3700). Based on the number of erythrocytes the samples were further diluted (using saline) before injecting to the rat [33].

\subsection{Experimental Procedure}

After 5 days of acclimatization, the animals were grouped (G) based on the body weight. G1 (normal control) received an oral suspension of $0.5 \%$ carboxy methyl cellulose-sodium salt via gavage. The G2 (disease control) group animals received pyrogallol at a dose of $100 \mathrm{mg} / \mathrm{kg}$ through intraperitoneal (i.p.) route once daily for 7 days. G3 group animals received the Biofield Energy Treated test formulation (1105.005 mg/kg b. wt, p.o.). G4 group animals received untreated test formulation at the same dose orally, while G5 group animals received levamisole at a dose of 50 $\mathrm{mg} / \mathrm{kg}$ p.o. from day 1 to 22 . All the animals except normal control group (G1) received pyrogallol at a dose of 100 $\mathrm{mg} / \mathrm{kg}$ through i.p. route once daily from day 1 to 7 . The animals were treated with the Biofield Energy Treated and untreated herbomineral formulation to the G3 and G4 animals respectively, 1 hour before pyrogallol challenge in the morning once daily for 22 days. On day $7^{\text {th }}$ and $13^{\text {th }}$, all the animals in G2 to G5 except G1 were challenged with sheep red blood cells (sRBC) $\left(0.5 \times 10^{9} / 100 \mathrm{gm} ;\right.$ i.p. $)$, as the antigenic material to sensitize them for immunological parameters. On day $13^{\text {th }}$ and $20^{\text {th }}$, blood was collected from retro orbital plexus and subjected to hemagglutination test to evaluate the immune response. On day $22^{\text {nd }}$, the animals were kept under fasting overnight and on next day, blood was collected again from retro orbital plexus from each animal under anaesthesia using isoflurane for haematological parameters and serum was analysed for biochemical examination. At the end of the study; animals were euthanized by $\mathrm{CO}_{2}$ asphyxiation as per in-house approved standard protocol.

\subsection{Assessment of Cellular and Humoral Responses}

Humoral immune response identification includes IgG and IgM estimated using Mini Vidas, Biomeurix (French) from serum, using commercially available kits. Flow cytometry was used to evaluate the $\mathrm{CD} 4^{+}$and $\mathrm{CD} 8^{+}$cells count and its ratio in blood as a measure of the cellular immune response. The mean values were calculated for each group. The percent change in the Biofield Energy Treated formulation group was calculated as compared to the vehicle control group. 


\subsection{Measurement of Hematology Parameters}

On $23^{\text {rd }}$ day of the experiment, blood was collected from the retro-orbital plexus using capillary tubes and hematology parameters such as total leukocyte count (TLC), and differential leukocyte count (DLC), neutrophil, lymphocyte, monocyte, and eosinophil were evaluated using Hematology analyzer (Abbott Model-CD-3700).

\subsection{Measurement of Lipid Profile and Hepatic Enzymes}

Serum biochemistry parameters such as total cholesterol (TC), triglycerides (TG), low density lipoprotein (LDL), high density lipoprotein (HDL), very low density lipoprotein (VLDL), alkaline phosphatase (ALP), serum glutamic oxaloacetic transaminase (SGOT), and serum glutamatepyruvate transaminase (SGPT) were analyzed in the test formulations.

\subsection{Measurement of Sex Hormone}

The level of testosterone was analyzed in serum in all the experimental groups using commercial kits. The $\%$ change in the test formulation group was calculated and compared.

\subsection{Statistical Analysis}

All the data were expressed as mean \pm standard error of mean (SEM) using Student's $t$-test to ascertain the statistical differences between the disease control and treated groups of the experiment. A probability level of $p \leq 0.05$ was considered as statistically significant.

\section{Results and Discussion}

\subsection{Measurement of Humoral Biomarkers (IgG and IgM)}

The effects of the Biofield Energy Treated and untreated test formulation on immunoglobulin levels ( $\mathrm{IgG}$ and $\operatorname{IgM}$ ) are presented in the Figure 1. The levels of IgG and IgM were increased in the Biofield Energy Treated test formulation group (G3) when compared to the disease control group (G2) Besides, IgG in the G3 group showed a better response and higher elevation compared with the untreated test formulation group $(\mathrm{G} 4)$. In case of $\operatorname{IgM}$, all the treated groups showed slight increases but non-significant elevation compared with the disease control group.

The levels of IgM in the normal control, disease control, Biofield Energy Treated test formulation, untreated formulation, and levamisole groups were reported as $0.15 \pm$ $0.01,0.13 \pm 0.02,0.19 \pm 0.02,0.21 \pm 0.02$, and $0.21 \pm 0.03$ $\mathrm{g} / \mathrm{L}$, respectively. However, the IgG levels in the normal group, disease control, Biofield Energy Treated test formulation, untreated formulation, and levamisole groups were reported as $2.00 \pm 0.28,2.48 \pm 0.18,2.85 \pm 0.08,2.31 \pm$ 0.13 , and $2.52 \pm 0.11 \mathrm{~g} / \mathrm{L}$, respectively. Overall, the levels of $\mathrm{IgM}$ and $\mathrm{IgG}$ in the Biofield Energy Treated test formulation group (G3) were increased by $46.15 \%$ and $14.92 \%$, respectively compared with the disease control group (G2). Besides, the IgG elevation level in the Biofield Energy Treated test formulation showed a better response as compared with the untreated test formulation (G4). However, the IgG level was decreased by $6.85 \%$, while IgM level was increased by $61.54 \%$ in the untreated formulation (G4) group compared with the G2 group.
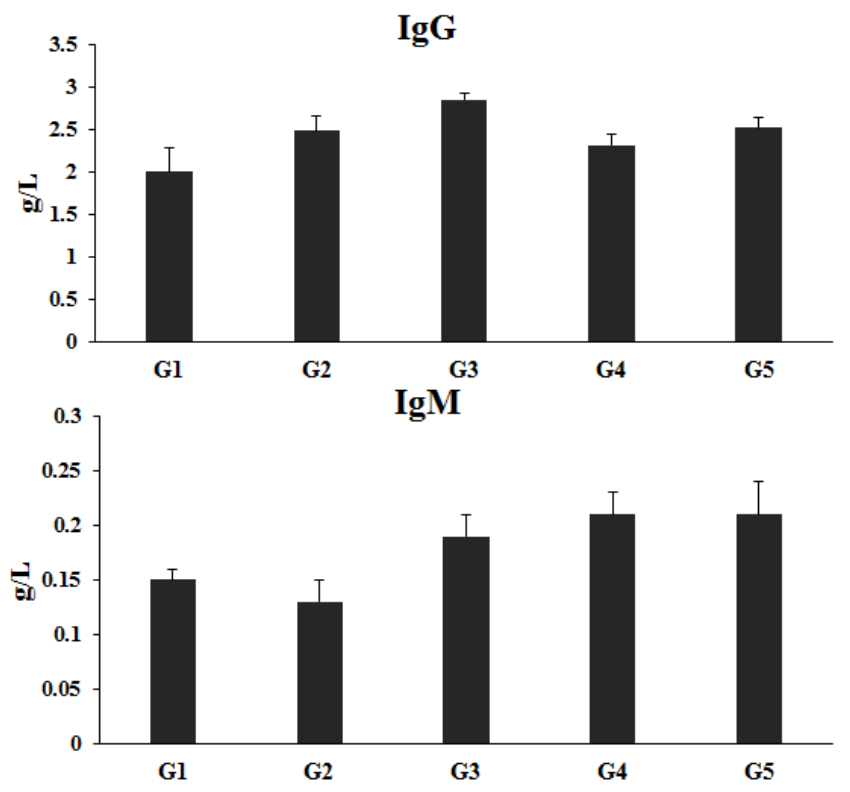

Figure 1. The effect of the test formulation on immunoglobulin levels, $\operatorname{Ig} G$ and IgM. G1: Normal control; G2: Disease control; G3: Biofield Energy Treated test formulation; G4: Untreated test formulation; and G5: Levamisole. All the values are represented as mean $\pm \operatorname{SEM}(n=6)$.

\subsection{Measurement of Cellular Biomarkers}

The results of $\mathrm{CD}^{+} / \mathrm{CD}^{+}$ratio in male $\mathrm{SD}$ rats after oral administration of the test formulation are demonstrated in the Figure 2. The $\mathrm{CD}$ markers i.e. the concentrations of $\mathrm{CD}^{+}$ and $\mathrm{CD} 8^{+}$were analyzed using whole blood samples. The ratio of $\mathrm{CD}^{+} / \mathrm{CD}^{+}$in the normal control (G1), disease control (G2), Biofield Energy Treated test formulation (G3), untreated test formulation (G4), and levamisole (G5) groups were $1.40,2.55,0.60,2.68$, and 4.33 respectively. The results suggest that the ratio was significantly decreased by $76.47 \%$ in the Biofield Energy Treated test formulation compared with the disease control group (G2). However, the levamisole group showed significant an increased $\mathrm{CD} 4^{+} / \mathrm{CD}^{+}$ratio by $69.80 \%$, compared with the disease control group. 


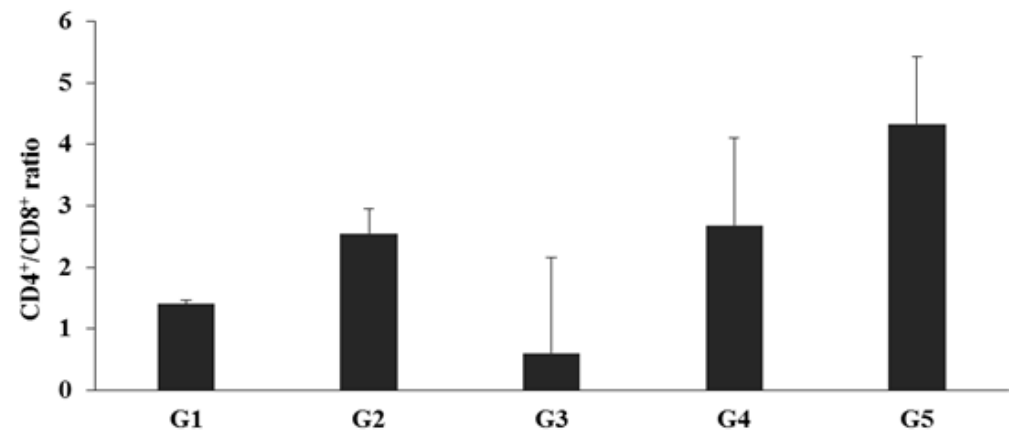

Figure 2. The effect of the test formulation on the ratio of cellular biomarkers $\left(C D 4^{+}\right.$and $\left.C D 8^{+}\right)$in male rats. G1: Normal control; G2: Disease control; G3: Biofield Energy Treated test formulation; G4: Untreated test formulation; and G5: Levamisole. All the values are represented as mean $\pm S E M$ ( $n=6$ ).

The ratio $\mathrm{CD}^{+} / \mathrm{CD}^{+}$reflects the health of the immune system. The present experimental results suggest that the Biofield Energy Healing Treatment significantly altered the ratio, so it can be concluded that The Trivedi Effect ${ }^{\mathbb{B}}$ might have the capacity to modulate the immune function in many autoimmune disease conditions.

\subsection{Measurement of Hematology Parameters}

The results of hematological parameters are summarized in the Table 1, which exhibited a significant effect from the test formulation after Biofield Energy Healing Treatment. The total leukocyte count (TLC) was increased in the G2 group as compared to the normal control group, while the percentage of neutrophils, lymphocytes, eosinophils, and monocytes was decreased in the disease control group (G2) compared with the normal control group (G1). However, the TLC, neutrophils, lymphocytes, and monocytes were found to be increased by $18.01 \%, 1.34 \%, 12.34 \%$ and $0.67 \%$, respectively in the Biofield Energy Treated test formulation (G3) group compared with the G2 group. Thus, it can be concluded that the Biofield Energy Treated test formulation improved the hematological profile compared with the untreated test formulation.

Based on the scientific literature, herbal products have demonstrated beneficial effects on hematological parameters. The outcome of a study from Madhuri and co-workers 2012, showed that Withania somnifera has a beneficial effect with improved hematological parameters such as TLC, neutrophils, lymphocytes, eosinophils, monocytes, hemoglobin, etc. in the rat model [34]. According to the study of Gautam et al. (2004) oral feeding of ashwagandha at $100 \mathrm{mg} / \mathrm{kg} / \mathrm{day}$ for 15 days to the laboratory animals showed improved blood profile [35], while Ziauddin et al. (1996) studied the boosting the effect of ashwagandha on the hematopoietic system [36].

The study result suggested that the Biofield Energy Treated test formulation can boost the immunological blood profile, such as TLC, neutrophils, lymphocytes, and monocytes. It can be assumed this stimulatory action of ashwagandha could be due the bone marrow cells, as studied by Davis and Kuttan (2000) [37]. They stated that at $20 \mathrm{mg} /$ dose/animal of ashwagandha root powder for 10 days injected (intraperitoneal) increased the presence of $\alpha$-esterase positive cells in the bone marrow, which results in stem cells enhancement and differentiation [37]. Besides, several reports support the beneficial role zinc, selenium, and magnesium supplementation to improve the hematology parameters [5-7]. Thus, it can be suggested that the herbomineral formulation showed an improved blood profile after treatment with the Biofield Energy Healing as compared with the untreated test formulation. It can be assumed that the healing energy of Biofield Energy Healers was transferred to the formulated product that could improve the overall activity of the test formulation.

Table 1. Effect of the test formulation on hematology parameters of male rats.

\begin{tabular}{|c|c|c|c|c|c|}
\hline Group & TLC (thousand $/ \mathrm{mm}^{3}$ ) & Neutrophils (\%) & Lymphocytes (\%) & Eosinophils (\%) & Monocyte (\%) \\
\hline 1 & $8.60 \pm 0.64$ & $20.33 \pm 1.23$ & $75.83 \pm 1.51$ & $1.83 \pm 0.40$ & $2.00 \pm 0.52$ \\
\hline 2 & $10.92 \pm 0.99$ & $16.33 \pm 1.76$ & $66.83 \pm 13.27$ & $1.33 \pm 0.21$ & $1.50 \pm 0.14$ \\
\hline 3 & $12.88 \pm 1.77$ & $17.67 \pm 1.43$ & $79.17 \pm 1.35$ & $1.00 \pm 0.00$ & $2.17 \pm 0.17$ \\
\hline 4 & $10.17 \pm 0.95$ & $18.67 \pm 1.99$ & $78.17 \pm 1.97$ & $1.17 \pm 0.17$ & $2.00 \pm 0.01$ \\
\hline 5 & $8.68 \pm 0.93$ & $21.00 \pm 1.48$ & $75.83 \pm 1.47$ & $1.17 \pm 0.17$ & $1.83 \pm 0.17$ \\
\hline
\end{tabular}

TLC: Total leukocyte count; G1: Normal control; G2: Disease control; G3: Biofield Energy Treated test formulation; G4: Untreated test formulation; and G5: Levamisole.

\subsection{Measurement of Lipid Profile}

The effects of the Biofield Energy Treated and untreated test formulations on the serum lipid profile are presented in the Table 2. Among the estimated parameters; a decreased level of total cholesterol $(67.04 \pm 3.25 \mathrm{mg} / \mathrm{dL})$, triglycerides $(65.66 \pm 7.23 \mathrm{mg} / \mathrm{dL}), \mathrm{HDL}(14.08 \pm 1.33 \mathrm{mg} / \mathrm{dL}), \mathrm{LDL}$ $(39.96 \pm 2.43 \mathrm{mg} / \mathrm{dL})$, and VLDL $(13.10 \pm 1.44 \mathrm{mg} / \mathrm{dL})$ were found in the Biofield Energy Treated test formulation (G3) as compared with the disease control group (G2). The lipid profile parameters such as total cholesterol, triglycerides, HDL, LDL, and VLDL were significantly decrease by $8.73 \%$, $10.96 \%, 6.26 \%, 8.60 \%$, and $11.01 \%$, respectively in G3 group as compared with the G2 group. Besides, the results suggest that the Biofield Energy Treated test formulation group (G3) showed a better profile of total cholesterol, 
triglycerides, LDL, and HDL as compared with the untreated test formulation group (G4). The reference standard levamisole (G5) group showed decreased levels of serum triglycerides and total cholesterol, and LDL as compared with the G1 group. With respect to serum lipids; there was a reduction in the HDL levels in the Biofield Energy Treated test formulation group as compared with the disease control and untreated test formulation groups. Besides, the LDL level was found to be decreased after the Biofield Energy Treatment on the test formulation as compared with the disease control and untreated test formulation groups.

Scientific reports suggest that the all the active constituents in the herbomineral formulation reported beneficial effects on the blood lipid profile. Individual ingredients such as ashwagandha root extract have been reported for significantly decreased levels of triglycerides, serum cholesterol, and altered LDL, VLDL levels. This showed the potential hypocholesterolemic effect of ashwagandha without any clinical adverse action [38]. Besides, selenium supplementation was reported to have a beneficial effect in lowering the serum total cholesterol, and LDL along with improved humoral immunity [39]. Similarly, zinc and magnesium supplementation were reported with an improved lipid profile such as decreased total cholesterol and LDL level, while increased HDL, cholesterol, and triglycerides levels [40, 41]. However, experimental results suggest that the Biofield Energy Treated test formulation showed a significantly improved lipid profile in comparison with the untreated test formulation. Biofield Energy Healing represents a low intensity electromagnetic field of energy of the Biofield Healers, and during treatment, it can be assumed that test formulation was exposed with the EMF, which displayed an improved animal lipid profile. A study report found that extremely low frequency EMF has a beneficial effect on the animal lipid profile i.e. decreased total cholesterol, LDL, and increased HDL levels [42]. Thus, it can be concluded that the Biofield Energy Treated test formulation showed a better hypocholesterolemic agent result as compared with the untreated test formulation.

Table 2. Effect of the test formulation on lipid profile parameters of male rats.

\begin{tabular}{llllll}
\hline Group (G) & Total Cholesterol (mg/dL) & Triglyceride (mg/dL) & HDL (mg/dL) & LDL (mg/dL) & VLDL (mg/dL) \\
\hline 1 & $73.13 \pm 4.90$ & $61.85 \pm 3.96$ & $15.82 \pm 0.96$ & $44.97 \pm 5.19$ & $12.35 \pm 0.79$ \\
2 & $73.45 \pm 2.25$ & $73.75 \pm 7.75$ & $15.02 \pm 0.65$ & $43.72 \pm 1.58$ & $14.72 \pm 1.55$ \\
3 & $67.04 \pm 3.25$ & $65.66 \pm 7.23$ & $14.08 \pm 1.33$ & $39.96 \pm 2.43$ & $13.10 \pm 1.44$ \\
4 & $82.27 \pm 6.52$ & $63.25 \pm 3.18$ & $15.27 \pm 0.85$ & $54.37 \pm 6.39$ & $12.63 \pm 0.63$ \\
5 & $95.18 \pm 5.02$ & $55.25 \pm 4.27$ & $17.23 \pm 2.33$ & $66.95 \pm 3.31$ & $11.00 \pm 0.86$ \\
\hline
\end{tabular}

HDL: High density lipoprotein; LDL: Low density lipoprotein; VLDL: Very low density lipoprotein; G: Group; G1: Normal control; G2: Disease control; G3: Biofield Energy Treated test formulation; G4: Untreated test formulation; and G5: Levamisole

\subsection{Measurement of Hepatic Biomarkers}

The effect of test formulation on hepatic parameters is presented in Table 3. The levels of SGOT, SGPT, ALP, total protein, albumin, globulin, and albumin/globulin ratio were decreased by $5.27 \%, 17.70 \%, 0.26 \%, 5.8 \%, 5.47 \%, 9.27 \%$, and $1.34 \%$ in the Biofield Energy Treated test formulation (G3) as compared to the disease control group (G2). The level of SGPT and SGOT was found as 47.55 \pm 4.06 and
$268.59 \pm 21.62 \mathrm{U} / \mathrm{L}$, respectively in the Biofield Energy Treated test formulation (G3). However, the levels of SGPT and SGOT were $57.78 \pm 11.07$ and $283.55 \pm 25.14 \mathrm{U} / \mathrm{L}$ respectively, in the diseases control groups (Table 3). However, the Biofield Energy Treated test formulation showed an altered level of hepatic biomarkers as compared with the disease control group.

Table 3. Effect of the test formulation on hepatic biomarkers of male rats.

\begin{tabular}{llll}
\hline Group (G) & TB (mg/dL) & SGOT (U/L) & SGPT (U/L) \\
\hline 1 & $0.13 \pm 0.01$ & $334.05 \pm 18.42$ & $36.57 \pm 1.75$ \\
2 & $0.13 \pm 0.02$ & $283.55 \pm 25.14$ & $57.78 \pm 11.07$ \\
3 & $0.13 \pm 0.01$ & $268.59 \pm 21.62$ & $47.55 \pm 4.06$ \\
4 & $0.19 \pm 0.03$ & $299.47 \pm 8.80$ & $41.92 \pm 3.92$ \\
5 & $0.12 \pm 0.02$ & $284.92 \pm 23.12$ & $50.37 \pm 5.13$ \\
\hline
\end{tabular}

Table 3. Continued.

\begin{tabular}{lllll}
\hline Group (G) & CK-MB (U/L) & TP (g/dL) & A (g/dL) & G (g/dL) \\
\hline 1 & $1265.30 \pm 109.14$ & $5.45 \pm 0.13$ & $3.40 \pm 0.03$ & $2.05 \pm 0.11$ \\
2 & $796.73 \pm 119.20$ & $5.68 \pm 0.08$ & $3.47 \pm 0.02$ & $2.38 \pm 0.18$ \\
3 & $825.75 \pm 77.15$ & $5.35 \pm 0.16$ & $3.28 \pm 0.04$ & $2.16 \pm 0.13$ \\
4 & $930.25 \pm 178.30$ & $5.98 \pm 0.07$ & $3.53 \pm 0.06$ & $2.45 \pm 0.08$ \\
5 & $933.37 \pm 52.65$ & $6.02 \pm 0.11$ & $3.57 \pm 0.02$ & $1.49 \pm 0.24$ \\
\hline
\end{tabular}

SGOT: Serum glutamic oxaloacetic transaminase; SGPT: Serum glutamate-pyruvate transaminase; ALP: Alkaline phosphatase; CK-MB: Creatine kinasemyocardial band; TB: Total bilirubin; TP: Total protein; A: Albumin; G: Globulin; A/G: Albumin/Globulin ratio. G1: Normal control; G2: Disease control; G3: Biofield Energy Treated test formulation; G4: Untreated test formulation; and G5: Levamisole 
The Biofield Energy Treated test formulation group (G3) showed a protective effect on the hepatic biomarkers compared with the untreated test formulation group (G4). The serum hepatic enzyme estimation is defined as the useful quantitative marker for the extent and type of damage of the hepatocellular damage. An increased level of enzymes reflects the structural damage of the liver, which results in an increased level of enzymes in the blood [43]. However, reports suggest that administration of ashwagandha has a protective response on the hepatic enzymes by normalizing the hepatic biomarkers [44]. Further, it was also reported that the minerals present in the test formulation have a significant importance in liver protection, which could prevent the prognosis of liver disease by stabilizing the membrane activity and hepatic biomarkers [45]. The experimental results exhibited that after Biofield Energy Treatment showed that the protective effect of the test formulation on liver enzymes was improved as compared with the untreated test formulation group. This suggests that the Biofield Energy Treated test formulation showed better efficacy in terms of hepatic protection against many diseases.

\subsection{Measurement of Sex Hormone}

The effects of the Biofield Energy Treated and the untreated test formulations on the level of testosterone are shown in the Figure 3. The levels of testosterone in the normal control, disease control, Biofield Energy Treated test formulation, untreated test formulation, and levamisole group were $2.46 \pm 0.67,0.98 \pm 0.54 .1 .37 \pm 0.76,0.96 \pm 0.52$, and $0.72 \pm 0.29 \mathrm{ng} / \mathrm{mL}$, respectively. Overall, in the Biofield Energy Treated test formulation group, the testosterone level was significantly increased by $39.8 \%$ compared with the disease control group. In the untreated test formulation group (G4), the testosterone level was decreased by $2.04 \%$ compared with the disease control group. Overall, the Biofield Energy Treatment on herbomineral formulation showed a better response compared with the untreated test formulation.

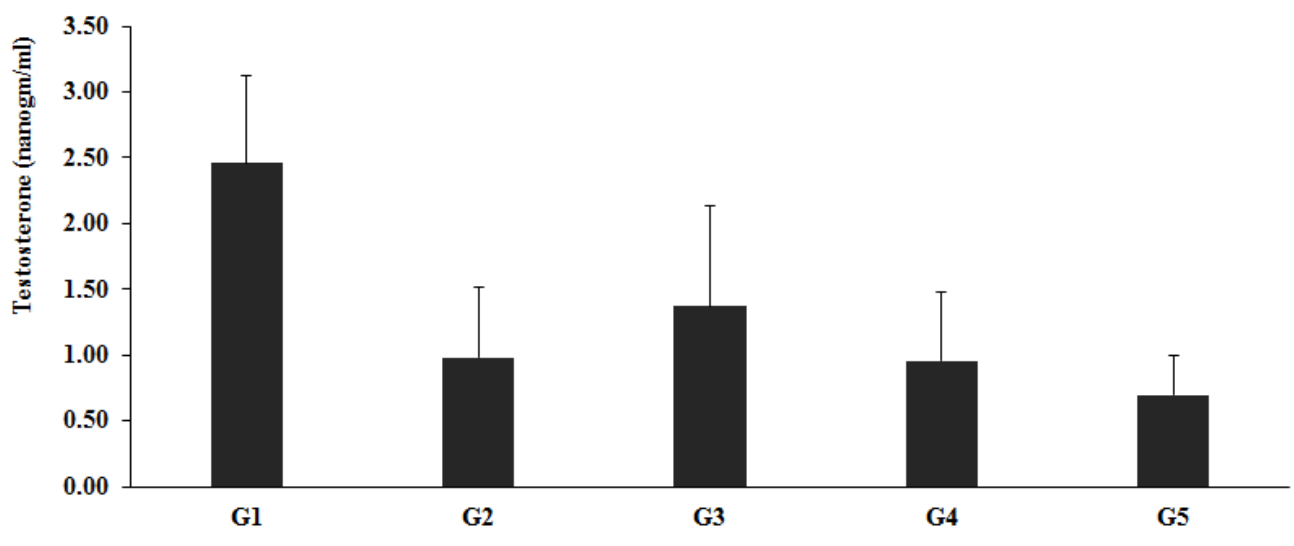

Figure 3. Effect of the test formulations on sex hormone. G1: Normal control; G2: Disease control; G3: Biofield Energy Treated test formulation; G4: Untreated test formulation; and G5: Levamisole.

According to the study outcome of Ambiye et al. (2013) ashwagandha has been used as traditional medicine and as an aphrodisiac by improving the semen parameters such as sperm count, motility, and volume. The report also suggested that the level of testosterone was significantly improved [46]. The scientific literature data suggest that all the individual constituents of the test formulation have significant effect to improve the male sexual dysfunction and infertility by improving the testosterone level. Similarly, added minerals in the test formulation has been reported with beneficial effect on the testosterone levels, such supplementation of zinc and selenium have significant effect on the serum-free testosterone levels [47]. Besides, magnesium supplementation also supports the significant increases in free as well as the total testosterone values [48, 49]. The study results showed a $39.8 \%$ increased level of testosterone after supplementation with the Biofield Energy Treated test formulation, which indicates that the Biofield Energy Treatment significantly enhanced the activity of the test formulation that can be used against many autoimmune and anti-inflammatory related disorders.

\section{Conclusions}

From the above experimental study, the results showed the significant immunomodulatory potential of the The Trivedi Effect $^{\circledR}$ - Energy of Consciousness Healing Treatment on test formulation. Humoral immune response parameters showed a significantly increased level of $\operatorname{IgM}$ and $\operatorname{IgG}$ by $46.15 \%$ and $14.92 \%$, respectively in the Biofield Energy Treated test formulation group (G3) compared with the disease control group (G2). However, the ratio of the cellular biomarkers $\left(\mathrm{CD}^{+} / \mathrm{CD}^{+}\right)$was altered by $76.47 \%$ in the Biofield Energy Treated test formulation group (G3) compared with the disease control group (G2). Hematological data showed improved parameters like TLC, neutrophils, and lymphocytes counts that were significant increased by $18.01 \%, 1.34 \%$, and $12.34 \%$, respectively in the Biofield Energy Treated test formulation (G3) group compared with the G2 group. The lipid profile parameters showed decrease percentage of total 
cholesterol, triglycerides, LDL, and VLDL by $8.73 \%$, $10.96 \%, 8.60 \%$, and $11.01 \%$, respectively in the Biofield Energy Treated test formulation group compared with the G2 group. Hepatic parameters showed decreased levels of SGOT, SGPT (17.70\%), ALP, total protein, albumin, globulin, and albumin/globulin ratio in the Biofield Energy Treated test formulation (G3) group compared with the G2 group. Besides, the testosterone level was significantly increased by $39.8 \%$ in the G3 group compared with the G2 group.

Overall, it can be concluded that the novel herbomineral formulation after treatment with the Trivedi Effect ${ }^{\circledR}$ - Energy of Consciousness Healing Treatment done remotely by the eighteen Biofield Energy Healers enhanced the herbomineral test formulation's anti-inflammatory and immunomodulatory properties without any side effects, which can be used to improve the overall health. Therefore, the Biofield Energy Treated test formulation may act as an effective antiinflammatory and immunomodulatory product, and it can be used as a Complementary and Alternative Medicine (CAM) with a safe therapeutic index for various autoimmune disorders such as Lupus, Systemic Lupus Erythematosus, Fibromyalgia, Addison Disease, Hashimoto Thyroiditis, Celiac Disease (gluten-sensitive enteropathy), Multiple Sclerosis, Dermatomyositis, Graves' Disease, Myasthenia Gravis, Pernicious Anemia, Aplastic Anemia, Scleroderma, Psoriasis, Rheumatoid Arthritis, Reactive Arthritis, Type 1 Diabetes, Sjogren Syndrome, Crohn's Disease, Vasculitis, Vitiligo, Chronic Fatigue Syndrome and Alopecia Areata, as well as inflammatory disorders such as Irritable Bowel Syndrome (IBS), Asthma, Ulcerative Colitis, Alzheimer's Disease, Parkinson's Disease, Atherosclerosis, Dermatitis, Hepatitis, and Diverticulitis. Further, the Biofield Energy Healing Treated test formulation can also be used in the prevention of immune-mediated tissue damage in cases of organ transplants (for example heart transplants, kidney transplants and liver transplants), for anti-aging, stress prevention and management, and in the improvement of overall health and quality of life.

\section{Abbreviations}

$\begin{array}{ll}\text { Abbreviation } & \text { Full Name } \\ \text { Na CMC } & \text { Sodium carboxymethyl cellulose } \\ \text { SD } & \text { Sprague Dawley } \\ \text { TC } & \text { Total cholesterol } \\ \text { TG } & \text { Triglycerides } \\ \text { LDL } & \text { Low density lipoprotein } \\ \text { HDL } & \text { High density lipoprotein } \\ \text { VLDL } & \text { Very low density lipoprotein } \\ \text { ALP } & \text { Alkaline phosphatase } \\ \text { SGOT } & \text { Serum glutamic oxaloacetic transaminase } \\ \text { SGPT } & \text { Serum glutamate pyruvate transaminase } \\ \text { TLC } & \text { Total leukocyte count } \\ \text { DLC } & \text { Differential leukocyte count } \\ \text { CK MB } & \text { Creatine kinase myocardium band } \\ \text { CAM } & \text { Complementary and alternative medicine }\end{array}$

\section{Acknowledgements}

The authors are grateful to the support of Dabur Research Foundation, Trivedi Science, Trivedi Global, Inc., and Trivedi Master Wellness throughout the work.

\section{References}

[1] Thomson GE (2007) The Health Benefits of Traditional Chinese Plant Medicines: Weighing the Scientific Evidence: A Report for the Rural Industries Research and Development Corporation, RIRDC, Barton, Australia.

[2] Rishton GM (2008) Natural products as a robust source of new drugs and drug leads: Past successes and present day issues. Am J Cardiol 101: 43D-49D.

[3] Mukhtar M, Arshad M, Ahmad M, Pomerantz R, Wigdahl B, Parveen Z (2008) Antiviral potentials of medicinal plants. Virus Res 131: 111-120.

[4] Wang JZ, Mao XJ, Ito H, Shimura K (1991) Immunomodulatory activity of polysaccharide from Acanthopanex obovatus roots. Planta Med 57: 335-336.

[5] Lukác N, Massányi P (2007) Effects of trace elements on the immune system. Epidemiol Mikrobiol Imunol 56: 3-9.

[6] Galland L (1988) Magnesium and immune function: an overview. Magnesium 7: 290-299.

[7] Wintergerst ES, Maggini S, Hornig DH (2007) Contribution of selected vitamins and trace elements to immune function. Ann Nutr Metab 51: 301-323.

[8] Ziauddin M, Phansalkar N, Patki P, Diwanay S, Patwardhan B (1996) Studies on the immunomodulatory effects of ashwagandha. J Ethnopharmacol 50: 69-76.

[9] Singh N, Bhalla M, de Jager P, Gilca M (2011) An Overview on Ashwagandha: A Rasayana (Rejuvenator) of Ayurveda. Afr J Tradit Complement Altern Med 8: 208-213.

[10] Mager J, Moore D, Bendl D, Wong B, Rachlin K, Yount G (2007) Evaluating biofield treatments in a cell culture model of oxidative stress. Explore (NY) 3: 386-390.

[11] Jain S, Hammerschlag R, Mills P, Cohen L, Krieger R, Vieten C, Lutgendorf S (2015) Clinical studies of biofield therapies: Summary, methodological challenges, and recommendations. Glob Adv Health Med 4: 58-66.

[12] Rubik B (2002) The biofield hypothesis: Its biophysical basis and role in medicine. J Altern Complement Med 8: 703-717.

[13] Trivedi MK, Patil S, Shettigar H, Mondal SC, Jana S (2015) The potential impact of biofield treatment on human brain tumor cells: A time-lapse video microscopy. J Integr Oncol 4: 141.

[14] Trivedi MK, Patil S, Shettigar H, Gangwar M, Jana S (2015) In vitro evaluation of biofield treatment on cancer biomarkers involved in endometrial and prostate cancer cell lines. J Cancer Sci Ther 7: 253-257.

[15] Trivedi MK, Patil S, Shettigar H, Mondal SC, Jana S (2015) In vitro evaluation of biofield treatment on Enterobacter cloacae: Impact on antimicrobial susceptibility and biotype. $\mathrm{J}$ Bacteriol Parasitol 6: 241. 
[16] Trivedi MK, Patil S, Shettigar H, Mondal SC, Jana S (2015) Evaluation of biofield modality on viral load of hepatitis B and C Viruses. J Antivir Antiretrovir 7: 83-88.

[17] Trivedi MK, Patil S, Shettigar H, Mondal SC, Jana S (2015) An impact of biofield treatment: Antimycobacterial susceptibility potential using BACTEC 460/MGIT-TB System. Mycobact Dis 5: 189.

[18] Trivedi MK, Branton A, Trivedi D, Nayak G, Mondal SC, Jana S (2015) Antimicrobial sensitivity, biochemical characteristics and biotyping of Staphylococcus saprophyticus: An impact of biofield energy treatment. J Women's Health Care 4: 271.

[19] Trivedi MK, Branton A, Trivedi D, Nayak G, Mondal SC, Jana S (2015) Evaluation of antibiogram, genotype and phylogenetic analysis of biofield treated Nocardia otitidis. Biol Syst Open Access 4: 143.

[20] Trivedi MK, Branton A, Trivedi D, Nayak G, Charan S, Jana S (2015) Phenotyping and 16S rDNA analysis after biofield treatment on Citrobacter braakii: A urinary pathogen. J Clin Med Genom 3: 129.

[21] Trivedi MK, Patil S, Shettigar H, Bairwa K, Jana S (2015) Spectroscopic characterization of chloramphenicol and tetracycline: An impact of biofield. Pharm Anal Acta 6: 395.

[22] Trivedi MK, Patil S, Shettigar H, Bairwa K, Jana S (2015) Spectroscopic characterization of biofield treated metronidazole and tinidazole. Med Chem 5: 340-344.

[23] Trivedi MK, Branton A, Trivedi D, Nayak G, Saikia G, Jana S (2016) Determination of isotopic abundance of ${ }^{2} \mathrm{H},{ }^{13} \mathrm{C},{ }^{18} \mathrm{O}$, and ${ }^{37} \mathrm{Cl}$ in biofield energy treated dichlorophenol isomers. Science Journal of Analytical Chemistry 4: 1-6.

[24] Trivedi MK, Branton A, Trivedi D, Shettigar H, Bairwa K, Jana S (2015) Fourier transform infrared and ultravioletvisible spectroscopic characterization of biofield treated salicylic acid and sparfloxacin. Nat Prod Chem Res 3: 186.

[25] Trivedi MK, Branton A, Trivedi D, Nayak G, Gangwar M, Jana S (2016) Molecular analysis of biofield treated eggplant and watermelon crops. Adv Crop Sci Tech 4: 208.

[26] Trivedi MK, Branton A, Trivedi D, Nayak G, Mondal SC, Jana S (2015) Morphological characterization, quality, yield and DNA fingerprinting of biofield energy treated alphonso mango (Mangifera indica L.). Journal of Food and Nutrition Sciences 3: 245-250.

[27] Trivedi MK, Branton A, Trivedi D, Nayak G, Mondal SC, Jana S (2015) Evaluation of plant growth, yield and yield attributes of biofield energy treated mustard (Brassica juncea) and chick pea (Cicer arietinum) seeds. Agriculture, Forestry and Fisheries 4: 291-295.

[28] Trivedi MK, Branton A, Trivedi D, Nayak G, Mondal SC, Jana S (2015) Evaluation of plant growth regulator, immunity and DNA fingerprinting of biofield energy treated mustard seeds (Brassica juncea). Agriculture, Forestry and Fisheries 4: 269-274.

[29] Trivedi MK, Tallapragada RM, Branton A, Trivedi D, Nayak G, Jana S (2015) Characterization of physical and structural properties of aluminum carbide powder: Impact of biofield treatment. J Aeronaut Aerospace Eng 4: 142.

[30] Trivedi MK, Nayak G, Patil S, Tallapragada RM, Latiyal O, Jana S (2015) Impact of biofield treatment on atomic and structural characteristics of barium titanate powder. Ind Eng Manage 4: 166.

[31] Trivedi MK, Patil S, Nayak G, Jana S, Latiyal O (2015) Influence of biofield treatment on physical, structural and spectral properties of boron nitride. J Material Sci Eng 4: 181.

[32] Trivedi MK, Nayak G, Patil S, Tallapragada RM, Latiyal O, Jana S (2015) Characterization of physical and structural properties of brass powder after biofield treatment. J Powder Metall Min 4: 134.

[33] Ladics GS (2007) Primary immune response to sheep red blood cells (SRBC) as the conventional T-cell dependent antibody response (TDAR) test. J Immunotoxicol 4: 149-152.

[34] Madhuri S, Pandey G, Khanna A, Shrivastav AB (2012) Effect of some herbal drugs on haematological profiles of rats. IRJP 3: 158-160.

[35] Gautam M, Diwanay SS, Gairolac S, Shinde YS, Jadhav SS, Patwardhan BK (2004) Immune response modulation to DPT vaccine by aqueous extract of Withania somnifera in experimental system. Int Immunopharmacol 4: 841-849.

[36] Ziauddin M, N Phansalkar, P Patki, S Diwanay, B Patwardhan (1996) Studies on the immunomodulatory effects of Ashwagandha. J Ethnopharmacol 50: 69-76.

[37] Davis L, Kuttan G (2000) Effect of Withania somnifera on DMBA induced carcinogenesis. J Ethnopharmacol 75: 165168.

[38] Andallu B, Radhika B (2000) Hypoglycemic, diuretic and hypocholesterolemic effect of winter cherry (Withania somnifera, Dunal) root. Indian J Exp Biol 38: 607-609.

[39] Bunglavan SJ, Garg AK, Dass RS, Shrivastava S (2014) Effect of supplementation of different levels of selenium as nanoparticles/sodium selenite on blood biochemical profile and humoral immunity in male wistar rats. Vet World 7: 10751081.

[40] Fox C, Ramsoomair D, Carter C (2001) Magnesium: Its proven and potential clinical significance. South Med J 94: 1195-1201.

[41] Payahoo L, Ostadrahimi A, Mobasseri M, Khaje Bishak Y, Farrin N, Asghari Jafarabadi M, Mahluji S (2013) Effects of zinc supplementation on the anthropometric measurements, lipid profiles and fasting blood glucose in the healthy obese adults. Adv Pharm Bull 3: 161-165.

[42] Torres-Duran PV, Ferreira-Hermosillo A, Juarez-Oropeza MA, Elias-Viñas D, Verdugo-Diaz L (2007) Effects of whole body exposure to extremely low frequency electromagnetic fields (ELF-EMF) on serum and liver lipid levels, in the rat. Lipids in Health and Disease 6: 31 .

[43] Giannini EG, Testa R, Savarino V (2005) Liver enzyme alteration: A guide for clinicians. CMAJ 172: 367-379.

[44] Sabiba EP, Rasool M, Vedi M, Navaneethan D, Ravichander M, Parthasarathy P, Thella SR (2013) Hepatoprotective and antioxidant potential of Withania somnifera against paracetamolinduced liver damage in rats. Int J Pharm Pharm Sci 5: 648-651.

[45] Nangliya V, Sharma A, Yadav D, Sunder S, Nijhawan S, Mishra S (2015) Study of trace elements in liver cirrhosis patients and their role in prognosis of disease. Biol Trace Elem Res 165: 35-40. 
[46] Ambiye VR, Langade D, Dongre S, Aptikar P, Kulkarni M, Dongre A (2013) Clinical evaluation of the spermatogenic activity of the root extract of Ashwagandha (Withania somnifera) in oligospermic males: A Pilot Study. Evid Based Complement Alternat Med 2013: 571420.

[47] Shafiei Neek, Gaeini AA, Choobineh S (2011) Effect of zinc and selenium supplementation on serum testosterone and plasma lactate in cyclist after an exhaustive exercise bout. Biol Trace Elem Res 144: 454-462.
[48] Cinar V, Polat Y, Baltaci AK, Mogulkoc R (2011) Effects of magnesium supplementation on testosterone levels of athletes and sedentary subjects at rest and after exhaustion. Biol Trace Elem Res 140: 18-23.

[49] Spallholz JE, Stewart JR (1989) Advances in the role of minerals in immunobiology. Biol Trace Elem Res 19: 129-151. 